$\begin{array}{ll}\text { le portiQue } & \text { Le Portique } \\ \text { Revue de philosophie et de sciences humaines }\end{array}$

$18 \mid 2006$

Heidegger. La pensée à l'heure de la mondialisation

\title{
The End of Philosophy in the Age of Democracy
}

\section{Gianni Vattimo}

\section{OpenEdition}

\section{Journals}

Édition électronique

URL : https://journals.openedition.org/leportique/811

DOI : 10.4000/leportique.811

ISSN : $1777-5280$

\section{Éditeur}

Association "Les Amis du Portique"

Édition imprimée

Date de publication : 1 septembre 2006

ISSN : 1283-8594

\section{Référence électronique}

Gianni Vattimo, "The End of Philosophy in the Age of Democracy », Le Portique [En ligne], 18 | 2006, mis en ligne le 15 juin 2009, consulté le 20 février 2023. URL : http://journals.openedition.org/ leportique/811 ; DOI : https://doi.org/10.4000/leportique.811

Ce document a été généré automatiquement le 20 février 2023.

Tous droits réservés 


\title{
The End of Philosophy in the Age of Democracy
}

\author{
Gianni Vattimo
}

1 When discussing the role of philosophy in late modern and postmodern societies, it is probably useful to underline the analogies that exist between a work such as "The Open Society and its Enemies" by Karl Popper and the ideas that Heidegger has discussed in many of his works, especially in a famous lecture entitled "The End of Philosophy and theTask of Thought" (1964). This is obviously a paradoxical approach, especially since Heidegger does not seem like a passionately "democratic" thinker. But the reasons that motivate Popper in lining up against Plato are basically the same that also move Heidegger in his polemic against "metaphysics", which, as he writes at the very opening of that lecture, has always been Platonism, that is, from the ancient times to Kant, Hegel and Nietzsche. In fact, if, instead of Popper's expression "Open Society", we use the Heideggerian term "Ereignis" or "Event", we shall betray neither the intentions of Popper nor those of Heidegger's. Even if neither of them would have approved of this small hermeneutical "violence".

2 Popper maintains that Plato was a dangerous enemy of the "Open Society" because he had an essentialist conception of the world. Therein, the real corresponds to a law given as the eternal structure of Being. A law to which society must simply conform. Since the one who really knows the essential order of things is the philosopher, he shall, naturally, be assigned the duty of commanding society. Indeed, the function that philosophers - and today scientists, technicians, experts - have claimed for themselves for centuries, namely, that of supreme advisors of the ruling princes, is closely entwined with this basic belief. According to which, all individuals and societies should confrom to an objectively given order. An order which is, moreover, regarded as the sole valid source and ground of all moral norm.

Indeed, a modern principle such as the one that stipulates that "auctoritas, non veritas, facit legem" has always been subject to rationalistic critiques inspired by "metaphysics" even when such critiques were underpinned by the best revolutionary intentions. For, in politics, wherever we are faced with the "Truth", there arises the 
danger of authoritarianism, that is to say, the very "closure" that Popper stigmatizes in his above-mentioned work.

4 Now, what Heidegger calls "metaphysics" is precisely the idea that Being is an order that is objectively given once and for all. This is also what Nietzsche reproaches Socrates with having promoted in as much as, in Socrates, he sees the beginning of modern decadence and the killer of the great tragic spirit of the ancient Greeks. If Being is a stable structure given once and for all, then there can be no possible openness in history. Nor can there be any "real" freedom.

Clearly, such a vision of Being is far more reassuring than the tragic one which, purportedly, characterized the worldview of pre-Socratic thinkers at the dawn of Greek thought.

Yet, such a reassurance, one could argue, functions especially well for those who are secure in the existing order of things and who, for this very reason, deem it as rational and blessed with eternal validity. (Here, besides Nietzsche, one could also recall the thesis of Benjamin concerning the philosophy of history). In the first pages of the aforementioned lecture on the end of philosophy, Heidegger refers to (besides Plato) Karl Marx as the thinker who, before Nietzsche, had already embarked on the "Inversion" ("Umwendung") of "metaphysics" and that of Platonism. With this, I do not mean to say that it is possible to somehow fill the gap between the Marxist "Inversion" of metaphysics and its "Overcoming" ("Überwindung") which Heidegger tries to prepare through his own work.

7 But neither is it absolutely irrelevant to refer to Marxist ideas on the origins of the alienation underlying the social division of labour in a capitalist economy when one attempts to understand, with Heidegger, why and how "metaphysics" has come to establish itself in such a radically irremovable manner in the context of the history of our world.

Here, I would also like to set aside the debate on the "historical" or the "eternal" character of "metaphysics" in Heidegger's thought, that is to say, a theme whose examination could probably help highlight Heidegger's conceptual dependence on the biblical myth of the "original sin". A myth of which Heidegger could never completely rid himself. Although the notion of "metaphysics" is employed by Heidegger in a rather peculiar way, I think that the analogy, even if paradoxical, with Popper could help clarify in which sense this term is also used by much contemporary philosophy. Thus, for example, it should not be difficult to recognize it in Wittgenstein ("Die Welt ist alles was der Fall ist. The world is everything that is the case: Tractacus, 1"), and, of course, in Pragmatism and Neopragmatism.

9 Some philosophers still refer to "metaphysics" in a way that is terminologically concordant with the classical tradition of thought as well as Neo-scholasticism, particularly that peculiar brand of Neo-scholasticism that is analytic philosophy.

In which, "metaphysics" is identified with a set of rigid "regional ontologies", i.e., the formal structures and conditions of knowledge. Structures whose conception is deprived of the elasticity and the historicity still recognizable in the transcendental categories of Kant and those of Husserl's.

11 Nevertheless, it is clear that a great part of contemporary philosophy rejects "metaphysics" in the Heideggerian sense, that is to say, as the identification of true "Being" with a stable structure that is both objectively recognizable and socially 
elevated as the source of all rules and norms. Even if, as is oft the case, no explicit reference is made to Heidegger himself. It is precisely on the basis of this rejection of "metaphysics" understood in the above sense - one that may be underpinned by Nietzschean-Heideggerian reasons or by the arguments of Wittgenstein, Carnap or Popper - that I would like to examine the problem of the end of philosophy in the era of democracy. Better still, by going beyond Heidegger and Popper, I shall argue that we could simply identify the end of "metaphysics" with the practical and the political affirmation of democratic regimes.

In a democracy, there is no class composed of holders of the real and absolute "Truth" whose members either directly exert power (Plato's king-philosophers ) or provide the sovereign with the appropriate rules of behaviour. This is why, in my view, the reference to Marx in Heidegger's lecture is quite symptomatic.

One may recall that, therein, the major theme is the end of philosophy as a consequence of its dissolution in the aftermath of the growing specialization of particular sciences such as, for example, psychology, sociology, anthropology, logic, logistics, semantics and cybernetics (contemporary computer science).

It's easy to see that this is not at all an abstract theme for those of us who teach philosophy at schools and universities and thereby experience the progressive dissolution of philosophy. In the universities, where new courses of psychology, anthropology and computer science are continually set up, enrollment in philosophy courses has rapidly decreased. Funds devoted to philosophical studies are reduced as well. In the end, all this may seem both very reasonable and yet unpleasant for many of us and our students. Such a phenomenon may appear to be merely an aspect of the end of philosophy, one that has nothing to do with democracy. Its emergence could simply be ascribed to the increasing autonomy of the human sciences. But, as Heidegger points out, it also reflects the growing social power and prestige of specialists. A prestige whose growth portends much greater "scientific" - and less democratic - control on various aspects of contemporary collective life.

In view of all this, one can readily understand that the end of philosophy leaves behind a vaccum that democratic societies must take into account.

On one hand, philosophy in the sense of the doctrinal supervision of the government of the "Polis" by the wise is dead. On the other, as suggested by the title of Heidegger's lecture that refers to the "Task of Thought" ("die Aufgabe des Denkens") after the end of philosophy, the specifically democratic problem of our era remains that of preventing that the authority of the erstwhile king-philosopher be substituted by the uncontrolled power of modern day technicians in different sectors of contemporary social life.

17 The latter is a far more dangerous power because it is both more subtle and fragmented. So much so that the erstwhile revolutionary goal of "striking at the heart of the state" appears totally unrealistic given that, today, power is distributed among many centres. Were one to use a psychiatric metaphor, one might say that, with the end of philosophy and its dissolution in specialized sciences, our world runs the risk of becoming a schizophrenic one where, sooner or later, a new supreme power will have to arise in order to make collective life as such possible, even at the cost of our freedom.

One could then change the title of Heidegger's lecture into: "The End of Philosophy in Democratic Societies and the Political Task of Thought". 
The sovereign role of the philosopher has ended since the role of sovereigns as such has ended and belongs to the past. It is not easy to say whether these "endings" are linked in a cause-effect relationship. Like Marx, Heidegger would say that the end of "metaphysics" and, consequently, that of philosophy's claim to absolute doctrinal sovereignty did not occur because of philosophers. In his view, this is an "Event" of Being to which the philosopher has to "respond".

Indeed, the difference between Heidegger and Marx would look rather slight were one to ask where does Being, to which the philosopher must "respond", speak?

Being does not speak in the economic-material "structure" of society, as Marx would say or, in any case, not exclusively there. But when Heidegger encourages us in not satisfying ourselves with the "daily presentation of what is present as present-at-hand" ("die vorhandene Gegenwaertigung des Anwesenden" in "Zur Sache des Denkens", Niemeyer 1969, page 79), we are not just superficially reminded of the Marxian critique of ideology, that of the "School of Suspicion" whose basic view is expressed, for example, in Brecht's slogan - "what always happens, do not consider it normal".

The analogy between Heidegger's critique of "metaphysics" and Popper's apology of the "Open Society" - which would have appeared absolutely unthinkable and remains relatively scandalous even today - is not merely a "theoretical" discovery. It "corresponds" to, that is to say, reflects and interprets the new conditions of our time. For, in comparison to the period in which Heidegger and Popper produced their respective philosophical works, the world of today appears much more strongly "rationalized" and "scientifically organized".

23 Likewise, the phenomenon of the end of philosophy and the corresponding structural schizophrenia that the progress of specialized sciences and technologies promotes, as mentioned above, to the point of foreshadowing the possible rise of a new brand of authoritarianism (I am thinking of George Bush's America, of course, but not exclusively) is infinitely more visible and pervasive. Hence, when I propose the thesis of the relative and paradoxical proximity of Heidegger and Popper, I do not claim that such a comparison can lead us to discovering a more profound "truth" for that would still constitute a "metaphysical" contention (coupled with its characteristic claim to absolute validity).

Rather, mine is simply an attempt at "cor-responding" - through the foregoing interpretation - to the "Event" in the specifically Heideggerian sense of the term, that is to say, the concrete situation in which we have all come to live.

25 Following Heidegger, Marx but perhaps not Popper (even though one could argue that such is the case for him as well), "The Task of thought" in this situation is to think what remains "hidden" in the "everyday presentation" of what usually happens. For Marx, it is the dialectical concreteness of interrelations that is concealed by the false consciousness of ideology and for Heidegger it is truth as "alétheia" or the basic openness of a horizon (one might speak of a paradigm) which makes possible all "Truth" meant as "correspondence" to a given state of affairs.

6 Be such a "correspondence" a matter of verification or falsification of propositions. As I have already stated, it is not immediately clear whether this effort at thinking what remains "hidden" in the "everyday presentation" of the world corresponds to Popper's idea of the task of philosophy as well. Indeed, it would seem that the reference to Marx (whom Popper appreciated) and the "hidden" that remains to be thought 
would take one far away from the notion of the "Open Society". This problem can not be discussed at length here and thus one could set aside the specifics of Popper's view of the task of philosophy.

As for Heidegger and Marx, the question is whether one may speak of Heidegger's "hidden alétheia" as if it were identifiable with the concreteness of the socio-economic interrelations of Marx's materialism. In other words, how can one define the task of thought in an epoch in which philosophers no longer (believe that they) have a privileged access to the eternal "Truth"? A belief on whose basis they would be entitled to govern society or act as the supreme advisors of the sovereign. Were we to follow Marx exclusively, we would return to a "metaphysical" and rationalistic historicism wherein the task of philosophers would be that of expressing the definitive "Truth" of history. One that can only be grasped by the expropriated proletariat and made through a revolution spearheaded by it.

If, on the contrary, we were to follow Heidegger exclusively, we would risk finding ourselves entangled in that "groundless mysticism, bad mythology, dangerous irrationalism" " "grundlose Mystik, schlechte Mythologie, verderblicher Irrationalismus" in "Zur Sache des Denkens", cit., ibid.) with which, as Heidegger points out in the mentioned lecture from 1964, the interpretation of his thought has been invariably bedeviled. In order to avoid such risks, which bedevil not just the interpretation of Heidegger's thought but that of several contemporary philosophies (at least those which don't wish to become harmless adjuncts of specialized human sciences), one must advance on the path of, to borrow Jurgen Habermas'famous definition of Hans Georg Gadamer's hermeneutics, "the urbanization of the Heideggerian province".

This could mean, I would argue, that one could draw upon an undeveloped passage of Heidegger's lecture on "The Origin of the Work of Art" (1936).

In that essay, Heidegger, as is well known, defined the work of art as the "putting into work of the truth", that is to say, the site of the occurrence of the "Event" of Being and the opening of a specific historial epoch.

31 From that moment on, Heidegger developed his "ontology" mainly, if not exclusively, on the basis of the idea of the "Event" ("Ereignis").

Heidegger repeatedly attempted to "en-own" ("er-eigen") the "Event" of Being by listening to the founding and inaugural words of great poets such as Hölderlin or the ancient wisdom contained in the statements of pre-Socratic philosophers such as Anaximander. But in the mentioned essay from 1936, he also refers to, without further explanations, other modes of the opening of "truth", i.e., of the "Event" of Being. Among them, there is also "the foundation of a state", that is to say, politics.

It is very likely that he did not develop his meditation on this point because of his unhappy involvement with the Nazis. Nevertheless, I argue that it is important to recall this allusion to politics as a possible site of the occurrence of the "Event" of Being since, in the era of democracy, the inaugural "Event" of Being may no longer be the work of art, but, in some sense, the political "Agorà". In the epoch of "metaphysics", the "Event" of Being occurred in those privileged ontological contexts that were the great works of art. In this respect, one should equally bear in mind that the great works of art of the past had always been entwined with the power of the sovereigns (painting, architecture, theatre, music, and even poetry in different senses). In those privileged 
expressions, Being still spoke in the form of an "Essential Truth" which entitled or, at least, purportedly entitled the philosopher to the absolute sovereignty of his doctrine.

One may conlude, albeit provisionally, that if we wish to "cor-respond" to the "Event" of Being in our specific historical situation, we shall have to listen to its voice in a context that is more akin to politics than art, or, for that matter, any privileged site of a profound and invisible announcement as such. I have proposed to describe this kind of thought with a term coined by late Foucault, namely, "l'Ontologie de l'Actualité" or "the Ontology of the Present".

The "Event" of Being to which thought has the task of "cor-responding" in the epoch of democracy presupposes and bespeaks the manner in which Being dispenses itself, from time to time, in the context of our collective experience.

The "hidden" which tends to remain "un-thought" against the backdrop of increasing specialization of contemporary sciences is the "on he on", that is to say, Being as Being or the whole of our individual and social experience that must be subtracted and freed from the grip of modern technological schizophrenia and its corollary risk of relapse into authoritarian social discipline.

Here, if one still speaks of "ontology" and thereby entrusts philosophers, once again, with the undertaking of such a crucial task - even though they no longer act as sovereigns or the supreme advisors of the sovereign - this could only mean that a new and still undefined social role for the "intellectual" must be imagined. One that would more closely resemble that of the "artist" and or the "priest" than those of the scientist, the technician or the technocrat.

In any case, the "priest" in question here would be one without a hierarchical church and the "artist" would be more of a "street artist".

In a less picturesque manner, we might characterize this role as that of a historian's and a politician's, that is to say, someone who does "ontology" in so far as he helps connect our contemporary experiences with those of our past history as well as those of other cultures and societies. Indeed, building and rebuilding such a sense of continuity encapsulates the very meaning of the term "logos" or dis-course. Here, I am also led to think of the idea of the philosopher as a "translator" ("Dolmetscher") propounded by Jurgen Habermas.

Does all this have anything to do with "Being", one might ask? We may well respond: is "Being" anything different or more profound and "hidden" than its "Event"?

Le texte de Gianni Vattimo fut présenté, pour la première fois et sous la forme d'une conférence, au cours du XXI Congrès international de Philosophie organisée par l'Association Internationale de Philosophie à Istanbul entre le 10 et le 17 août 2003. La traduction de ce texte écrit à l'origine en italien a été revue par Simon F. O'Li (Oliai).

\section{RÉSUMÉS}

«La fin de la philosophie dans l'âge de la démocratie » 
L'époque actuelle est celle de la fin de la philosophie. Une telle fin équivaut à l'abandon irréversible de la notion platonicienne de "Vérité » comprise comme l'expression d'un ordre éternel et objectif de tout « ÊTRE ». L'époque actuelle est aussi celle de l'émergence ainsi que de la consolidation progressive de sociétés démocratiques.

On objectera que, en démocratie, l'ancienne suprématie d'une caste politique et intellectuelle, fondée sur sa revendication "métaphysique » de la possession exclusive de l'absolue "Vérité de l'ÊTRE ", doit nécessairement être rejetée en faveur d'une conception ouverte de l'ÊTRE comme «Événement » («Ereignis ») ce qu'Heidegger a continuellement rappelé après la publication de sa célèbre conférence sur l'origine de l'oeuvre d'art en 1936. La préoccupation essentielle qui sous-tend la façon dont Heidegger met en valeur le caractère réducteur de la conception «métaphysique» de l'ÊTRE chez Platon est partagée par une grande partie de la philosophie contemporaine. En effet elle peut servir à établir, quoique paradoxalement, des parallèles entre certains arguments de textes tardifs et cruciaux de Heidegger comme l'essai de 1964 sur la «Fin de la philosophie et la Tâche de Pensée » et ceux des philosophes apparemment antithétiques comme Popper l'a exposé dans La Société ouverte et ses ennemis. On objectera que la tâche majeure de toute réflexion philosophique lucide est de préserver ce qui reste caché dans la présentation quotidienne de ce qui transparaît dans un monde fortement rationalisé. Un monde dans lequel le déclin de l'absolu dans l'ontologie et l'influence sociale croissante de l'expertise technique peut encourager un relaps vers le contrôle social autoritaire. Dans un tel contexte, le rôle principal de la philosophie est d'affirmer le caractère irréductible de l'Événement de l'ÊTRE en tant que tel (on he on) et la liberté politique que sa dispensation présuppose.

"The End of Philosophy in the Age of Democracy"

The current era is that of the "end" of philosophy. Such an "end" is tantamount to the irreversible abandonment of the Platonic notion of "Truth" understood as the expression of an eternal and objective order of all "Being". The current era is also that of the emergence as well as the progressive consolidation of democratic societies.

It shall be argued that, in a democracy, the erstwhile political supremacy of a specific political and intellectual caste (based on its "metaphysical" claim to the exclusive possession of the absolute "Truth of Being") must necessarily be discarded in favour of an open conception of "Being" as "Event" ("Ereignis") which Heidegger consistently drew upon after the publication of his famous conference on the origin of the work of art in 1936. The anti-essentialist concern underlying Heidegger's manner of highlighting the reductive character of Plato's "metaphysical" conception of "Being" is shared by much contemporary philosophy. Indeed, it can serve to establish, albeit paradoxically, parallels between some of the arguments of Heidegger's crucial later texts such as the 1964 essay on "The End of Philosophy and the Task of Thought" and those of such seemingly antithetical philosophers as Popper's expounded in "Open Society and its Enemies". It shall be argued that the major contemporary task of all lucid philosophical reflection is that of preserving what remains "hidden" in the everyday presentation of what transpires in a strongly rationalized world. A world in which the decline of the absolute in ontology and the growing social influence of technical "expertise" may encourage a relapse into authoritarian social control. In such a context, the principal role of philosophy is that of affirming the irreducible character of the "Event" of "Being" as such ("on he on") and the political freedom that its dispensation presupposes.

La época actual es la época del final de la filosofía. Este final significa el abandono irreversible de la noción platónica de "verdad», entendida como la expresión de un orden eterno y objetivo de cada «SER ». La época actual es también la época de la emergencia y de la consolidación progresiva de las sociedades democráticas. El papel principal de la filosofía es afirmar el carácter irreductible del Acontecer del Ser en sí y la libertad política que presupone su distanciación. 
"Das Ende der Philosophie im Zeitalter der Demokratie"

Die heutige Zeit entspricht dem Ende der Philosophie, das heisst dem unwiderruflichen Verzicht auf die platonische Idee der Wahrheit als Ausdruck einer ewigen Ordnung und als Ziel eines jeden "Wesen". Das heutige Zeitalter sieht auch die Emergenz und die progressive Konsolidierung der demokratischen Gesellschaften. Die hauptsächliche Rolle der Philosophie besteht darin den unreduzierbaren Charakter des "Ereignisses" vom "Sein" zu behaupten, sowie die Voraussetzung der politischen Freiheit als nötige Distanz

\section{AUTEUR}

\section{GIANNI VATTIMO}

Gianni Vattimo est une figure majeure de la philosophie contemporaine. Il est aussi professeur de philosophie théorique à l'Université de Turin et ex-parlementaire européen. Parmi ses écrits décisifs, on peut citer L'Avventure della differenza $(1980,1988)$, La Fine della modernità (1985, 1991), Il Pensiero Debole avec Pierre Aldo Rovatti (1984), Credere di Credere (1996, 1999), Nietzsche, Heidegger e l'Ermenuetica (1984) et Dialogo con Nietzsche (2000). 